\title{
Population Health Metrics: the next phase
}

\author{
Jonathan M. Samet ${ }^{1 *}$, Christopher J. L. Murray ${ }^{2}$ and Alan D. Lopez ${ }^{3}$
}

First published in 2003, Population Health Metrics has evolved into a leading international journal for those concerned with how to measure the health of populations and to assess the consequences of interventions to improve population health. Interest in these broad methodological topics has grown substantially since the journal was launched as goals have been set for advancing health, e.g., the Sustainable Development Goals, and increasing calls by the global health community for accountability as to what has been accomplished by programs and policies that have been implemented and by funds expended. Over the years, since the journal was founded, the term "population health" has become ever more widespread in its usage, now extending to the health care domain in the USA, for example. The term has the advantage of an implied inclusive breadth that extends beyond the concept of "public health".

That breadth is illustrated by the range of papers published by Population Health Metrics. The journal has given emphasis to novel methods for measuring and tracking population health, while addressing such topics as tobacco use, air pollution, verbal autopsies, infectious diseases and, non-communicable diseases. It stands out for bringing together papers on innovative methods with papers showing how such methods deepen understanding of population health and its determinants.

That breadth is further exemplified by considering some of the journal's most cited papers (Table 1 ).

The journal is publishing around $20-30$ papers per year. The 2-year Impact Factor has remained comparatively steady around 2.8/2.9, whilst the 5-year Impact Factor is currently 3.616. This figure ranks the journal as one of the top 5 Open Access journals within the SSCI category 'Public, Environmental \& Occupational Health'.

In 2017, BMC signed the San Francisco Declaration on Research Assessment (DORA) and as part of this, Population Health Metrics committed to presenting the Impact Factor in the context of a variety of journal-based metrics. These measures include the 2-year Impact Factor, 5-year Impact Factor, SCImago Journal Rank, Source Normalized

\footnotetext{
* Correspondence: JON.SAMET@CUANSCHUTZ.EDU

${ }^{1}$ Colorado School of Public Health, Aurora, CO, USA

Full list of author information is available at the end of the article
}

Impact per Paper (SNIP), article downloads, and article handling times. All of these metrics are openly available on the journal homepage.

This status report comes as the team of editors for Population Health Metrics changes. The founding Editors-in-Chief, Christopher JL Murray and Alan D Lopez stepped down in 2019 and are replaced by Jonathan M. Samet. A new team of Associate Editors and Editorial Board members is being recruited. The Scope and Aims of Population Health Metrics leaves its broad mission unchanged:

"Population Health Metrics aims to advance the science of population health assessment, and welcomes papers relating to concepts, methods, ethics, applications, and summary measures of population health."

The journal provides a unique platform for population health researchers to share their findings with the global community. We seek research that addresses the communication of population health measures and policy implications to stakeholders; this includes papers related to burden estimation and risk assessment, and research addressing population health across the full range of development.

Population Health Metrics covers a broad range of topics encompassing health state measurement and valuation, summary measures of population health, descriptive epidemiology at the population level, burden of disease and injury analysis, disease and risk factor modeling for populations, and comparative assessment of risks to health at the population level. The journal is also interested in how to use and communicate indicators of population health to reduce disease burden, and the approaches for translating from indicators of population health to healthadvancing actions. As a cross-cutting topic of importance, we are particularly interested in inequalities in population health and their measurement."

As a foundational principle, Population Health Metrics proposes that the ultimate goal of all of its papers should be to advance population health, both locally and globally. Looking to the future of population health and the journal's role, an increasing emphasis on studies addressing 
Table 1 Population Health Metrics' most cited papers

\begin{tabular}{|c|c|c|c|c|}
\hline Article title & $\begin{array}{l}\text { Corresponding } \\
\text { author }\end{array}$ & Year & $\mathrm{DOI}$ & $\begin{array}{l}\text { Number } \\
\text { of citations }\end{array}$ \\
\hline $\begin{array}{l}\text { Projection of the year } 2050 \text { burden of diabetes in the US adult } \\
\text { population: dynamic modeling of incidence, mortality, and } \\
\text { prediabetes prevalence }\end{array}$ & James P Boyle & 2010 & https://doi.org/10.1186/1478-7954-8-29 & 746 \\
\hline $\begin{array}{l}\text { National, regional, and global trends in adult overweight and obesity } \\
\text { prevalences }\end{array}$ & $\begin{array}{l}\text { Gretchen A } \\
\text { Stevens }\end{array}$ & 2012 & https://doi.org/10.1186/1478-7954-10-22 & 449 \\
\hline $\begin{array}{l}\text { Accuracy and completeness of mortality data in the Department of } \\
\text { Veterans Affairs }\end{array}$ & $\begin{array}{l}\text { Min-Woong } \\
\text { Sohn }\end{array}$ & 2006 & https://doi.org/10.1186/1478-7954-4-2 & 280 \\
\hline $\begin{array}{l}\text { A generic model for the assessment of disease epidemiology: the } \\
\text { computational basis of DisMod II }\end{array}$ & $\begin{array}{l}\text { Jan J } \\
\text { Barendregt }\end{array}$ & 2003 & https://doi.org/10.1186/1478-7954-1-4 & 211 \\
\hline $\begin{array}{l}\text { Comparative quantification of health risks: conceptual framework and } \\
\text { methodological issues }\end{array}$ & $\begin{array}{l}\text { Christopher } J \mathrm{~L} \\
\text { Murray }\end{array}$ & 2003 & https://doi.org/10.1186/1478-7954-1-1 & 209 \\
\hline The burden of disease and injury in Iran 2003 & $\begin{array}{l}\text { Mohsen } \\
\text { Naghavi }\end{array}$ & 2009 & https://doi.org/10.1186/1478-7954-7-9 & 192 \\
\hline $\begin{array}{l}\text { Mortality registration and surveillance in China: history, current situation } \\
\text { and challenges }\end{array}$ & $\begin{array}{l}\text { Gonghuan } \\
\text { Yang }\end{array}$ & 2005 & https://doi.org/10.1186/1478-7954-3-3 & 167 \\
\hline Global epidemiology of invasive meningococcal disease & Rabab Z Jafri & 2013 & https://doi.org/10.1186/1478-7954-11-17 & 166 \\
\hline $\begin{array}{l}\text { Algorithms for enhancing public health utility of national } \\
\text { causes-of-death data }\end{array}$ & $\begin{array}{l}\text { Mohsen } \\
\text { Naghavi }\end{array}$ & 2010 & https://doi.org/10.1186/1478-7954-8-9 & 163 \\
\hline Modeling causes of death: an integrated approach using CODEm & Kyle J Foreman & 2012 & https://doi.org/10.1186/1478-7954-10-1 & 162 \\
\hline
\end{tabular}

the consequences of policies, however enacted, can be anticipated. Tools for estimating burden have been refined and yielded results that are trusted and that have motivated action. The call for documentation of benefits of actions is ever louder, but providing answers can be challenging.

At this time of transition, the new editorial team thanks and acknowledges those who launched the journal, particularly Alan Lopez and Chris Murray, and the numerous contributors who served as Associate Editors, Editorial Board members, and reviewers.

\section{Authors' contributions}

All authors read and approved the final manuscript.

\section{Competing interests}

The authors declare that they have no competing interests.

\section{Author details}

${ }^{1}$ Colorado School of Public Health, Aurora, CO, USA. ${ }^{2}$ Institute for Health Metrics and Evaluation, Seattle, WA, USA. ${ }^{3}$ University of Melbourne,

Melbourne, Australia.

Received: 27 January 2020 Accepted: 27 January 2020

Published online: 05 February 2020

\section{Publisher's Note}

Springer Nature remains neutral with regard to jurisdictional claims in published maps and institutional affiliations.

Ready to submit your research? Choose BMC and benefit from:
- fast, convenient online submission
- thorough peer review by experienced researchers in your field
- rapid publication on acceptance
- support for research data, including large and complex data types
- gold Open Access which fosters wider collaboration and increased citations
- maximum visibility for your research: over 100M website views per year
At BMC, research is always in progress.
Learn more biomedcentral.com/submissions

